УДК 37.091.4:338.48-6:37

Yuliia O. Matviyiv-Lozynska

teacher of English language

Lviv Institute of Economy and Tourism, Lviv, Ukraine

lozynskajuliya@yahoo.com

\title{
USE OF INFORMATION TECHNOLOGIES IN EDUCATIONAL EXTRACURRICULAR ACTIVITIES IN HIGHER TOURIST INSTITUTIONS
}

\begin{abstract}
The article deals with extracurricular educational activities in higher educational establishment of tourism profile with information technologies usage. It is known that extracurricular activities of higher educational establishment has an impact on the professional activities of future specialists in the tourism industry, as is in the process of extracurricular activities students can put into practice the obtained knowledge and skills. The task of teachers is to build a learning process, in particular activities outside classrooms as its component, so that the students were interested in it. In the modern world of tourism prosperity it is very difficult to do without the usage of multimedia technologies (internet, media, etc).
\end{abstract}

Keywords: information technology, extracurricular activities, professional, tourist industry, education, higher educational establishment.

\section{INTRODUCTION}

The problem setting. Studying in higher educational establishment is the most important and prevailing factor in youth life who decided to master higher education. Here they produce social communication skills (relationship with the team and through it with the society), get acquainted with public activities, find opportunities to develop their abilities. Young man is as an individual, with its rules of conduct, principles, ideals, values $[3,45]$.

Information technologies are very important in education nowadays. Modern society requires new approaches to the organization of education, especially to extracurricular activities. We should create well-educated personality of a student in modern information society.

Youth can study in conditions of nonviolence, freedom, tolerant relations. Moreover, the educational establishment creating social, natural, cultural environment using its educational opportunities is to be and can become the center of a broad educational space. The modern higher educational establishment is to teach students the ability to defend their rights and at the same time respect the rights of others using knowledge of basic legal norms and the ability to use the power of state legal system. The necessity to act in the position of others, legal norms becomes a condition for the development of "I" of the student regarding "I" of other people [4, 65-66].

Higher educational institutions should provide opportunities for entry of the personality into the world educational space, forming valuable life prospects for peace, human rights, democracy, tolerance and social harmony supporting the preservation and promotion of World Heritage, mastering different languages[4, 27].

Educational work in educational establishments is necessary to be organized under conditions of concept of national system of education which is pledge for integral identity formation when "harmonically developed, well-educated, socially active and nationally conscious person who is with great civil responsibility, healthy intellectual, creative, physical and spiritual qualities of family and patriotic feelings of the work, economic smartness, entrepreneur activity and initiative $[8,55]$. Educational activities in higher educational 
institution are successfully integrated into the learning process, national and world culture. A special role in higher education should educate professional culture that is associated with the future profession students.

Nowadays tourism as one of the important socio-economic phenomena which is subordinated to the objective laws of human society development, "evolving in dialectic unity of all its components, creates a social space within which the raging interaction and competition, coherence and contradictions, conflicts and tourist life consensus history of which goes back into centuries "[11, 15]. Occupying a key position in the economic and social sciences tourism has become an indicator of economic development and international understanding to promote peace, prosperity and respect for human rights regardless of race, gender, language and religion.

According to the Code of tourist, Charter of tourism, Global ethic code of tourism duties and rules of conduct for tourists are defined. In particular, it is noted that a tourist has the right to rest and leisure time in harmony with the conditions, peculiarities and traditions of regions and countries that he visited following the laws, customs and traditions of these countries.

The importance of information technology in tourism, especially of the World Wide Web, has increased tremendously over the past years and this trend will certainly continue. However, since the technology itself is now available to almost everyone, its use alone does not necessarily bring a competitive advantage anymore. The integration of IT into extracurricular activity of higher tourist institutions is an important key to success. Integration means that technology, extracurricular activity and tourism are coordinated to achieve the desired effectiveness [13].

Nowadays educational work in higher educational establishments has shown that it is not systematic. This is especially concerns extracurricular educational work which is not sufficiently related to the educational process and is based primarily on the individual, onetime events and episodic interactions of social institutions staff and is characterized by low activity of student government and the lack of organizational and educational software [2]. Very often extracurricular activity is limited by some theoretical issues. It does not use any information progressive technologies to improve the intelligence of a student, to get to know the latest innovations in education.

Analysis of recent studies and publications. A significant amount of scientific works is devoted to the problem of educating students in higher educational establishments. (by J. Bech, S. Goncharenko, B. Stuparyk, O. Sukhomlynska, O. Abdullin, I. Avdeev, Yu. Babanskyi, O. Vyshnevskyi, V. Zhuk, C. Karpenchuk, O. Kondratyuk, A. Halyeyeva, V. Fedorchenko, N. Yaremchuk, T. Petrakova, T. Osypova etc.).

Scientists in particular Yu. Babanskyi, M. Kasyanenko, B. Bim-Bad, S. Bondarev, D. Kolesev, M. Fitsula etc., exploring the theory and methodology of education of young people consider aspects of tolerance forming. So, O. Sukhomlynska in the article "On the state of the theory and practice of education in the educational environment of Ukraine" notes that the primary mission of education should be in:

- the transmission of cultural values and

- in preparing young people to integrate into society and

- in leveling, reducing social inequality [10, 2-4].

The interpersonal communication and dialogue is of great importance in this context.

Despite the achievements in the sphere education of future specialists in tourism in higher educational establishment as well as organization of educational extracurricular activity and ways of ensuring its effectiveness have not been subject to specific pedagogical research that caused the choice of topic of the article.

The article's goal is to identify the characteristics of education of future specialists and 
the role of educational opportunities of extracurricular activities in higher educational establishments of tourism sphere.

According to the purpose of educational work in higher educational establishment is to solve a number of specific social and educational tasks, namely:

- deep and comprehensive mastering of the history and culture of the people;

- form an idea of the diversity of cultures in Ukraine and worldwide, understanding and internal acceptance of equality of peoples and their cultures equivalence, education of positive attitudes towards cultural differences as a factor of the development of world civilization and self-identity, education of positive attitude towards cultural differences to ensure the progress of all humanity and to promote fulfillment of the individual;

- creating conditions for integration of students in the cultures of other nations;

- development of skills of productive interaction with speakers of different cultures;

- peace education, development of ethnic tolerance;

- formation of perceived positive value orientations of individual concerning cultural heritage of Ukraine;

- respect for the history and culture of other nations: creating multicultural environment as a basis for interaction between the individual elements of other cultures;

- forming ability of the student to personal cultural self-determination $[9,41]$.

\section{METHODS OF THE STUDY}

In our study we use the following methods: theoretical - analysis of philosophical, pedagogical and psychological literature making it possible to clarify the nature of the basic concepts of research, systematization and generalization of theoretical and empirical data by which revealed the real state of multicultural education of future professionals of tourism in extracurricular work, empirical - monitoring, review documentation and performance that has created a knowledge base for the development of content, forms and methods of multicultural education of future professionals in the tourism industry.

\section{THE RESULTS OF THE STUDY}

Educating of students is of great importance in the formation of a specialist than his training. Lack of culture, formal attitude to professional duties, lack of moral systems can significantly reduce the quality of professional activity of specialist. It concerns the professions specialists of which are constantly working with people particularly of tourism industry.

The general objective of tourism is defined as the enrichment of the individual with moral and ethical values and updating the knowledge of cultural, health, development of adaptive capacity of an organism etc. Therefore, education of employees in tourism is not only an indicator of cultural identity but also the key to a successful professional activity of the specialist.

Peculiarities of future specialists education in tourism are to develop his professional abilities and skills based on the learned and application in practice. Characteristic features that future specialist in tourism industry should have is communicativeness, professional culture, tolerance, knowledge of his native land, fluency in foreign languages and respect for other nationalities and forming practical experience based on the values of different cultures.

The main directions and content of higher educational establishment in tourist sphere as educational system are defined in the work "Pedagogics of tourism" (Fedorchenko, N. Fomenko) [11, 59-60]: the study of students' individuality, determination of the initial level 
by various criteria of professional and pedagogical direction of future specialist, active citizenship education, a sense of motherland citizen, responsibility for its destiny, growing generation, professional dignity, education of intellectual culture, forming of abilities and skills of intellectual culture, interest to different scientific values, literature, art as especially important spiritual values of the order, education of necessity to self-education, moral education, the formation of spiritual culture, of civilized, human attitude to people, human development, promotion of environmental and economic culture, education of national self consciousness, feeling of pride and respect for national history, culture, traditions and customs of Ukrainian people respect and tolerant attitude toward people of other nationalities living in Ukraine, their national feelings, culture and customs, education of future specialists in tourism as speakers of human relations between people of different nationalities, ethnic groups, forming of political and legal culture, education of aesthetic culture of the future specialist in tourism in all forms of expression and the development of student government in the organization of educational work in groups, various clubs, dormitories, scientific and educational and methodical preparation of young teachers, educational curators to work with the students, providing communication regarding goals and objectives of the educational system, scientific-pedagogical and methodological assistance to teachers and others to educational institutions in the organization of their educational work.

There is no doubt that extracurricular work in higher educational establishments significantly affects the effectiveness of the overall educational process.

Extracurricular activity of students in higher educational establishments is realized to its forms. Information technologies are moving faster, so future specialists in tourism should not be left behind. Concerning forms-samples of using information technologies in extracurricular activities we can offer the following: using TV, commercials, Internet, movies etc. Students will create music videos, clay animation, utilize blue/ green screen technology, study videos from YouTube, upload video to the Internet and create videos on an iPad, cell phone or other personal media device. Such information can include tourist routes, advertisements etc. Students will have an opportunity to promote their expertise learned in Multimedia. Advanced techniques can be explored and applied. It can be treated like a job experience as students will develop layout and design for various tourist or community projects [12].

In scientific and educational literature widely covered concepts such as "individual", "group" and "mass" forms of extracurricular work are highlighted. All these forms are used in extracurricular activities of students in higher educational establishments.

A. Makarenko stated that the effectiveness of educational influence is not directly within it because the effectiveness is the product of systematic qualities. Therefore, the performance of educational activities is based on its inclusion in the system of measures [7].

Study of extracurricular activities of students showed that many of them use forms of work involving cycle, system of related extracurricular activities and reveal the appropriate theme or direction of students educating. Thus, the club form of work allows to plan a system of knowledge, the cycle of logically related educational activities, students educating in labor traditions of the Ukrainian people, to educate psychological and practical readiness to the work of the chosen profession [5]. In extracurricular activities of students of higher educational establishments systematic organizational and pedagogical forms should determine the club, lectures, group, etc. which provide a system of logically related extracurricular activities of relevant topics (aesthetic, legal, economic education, etc.). To systematic organizational and pedagogical forms of extracurricular activities of higher educational establishments belong student associations (production, socio-political, amateur, ecological, artistic, aesthetic, legal) are included. Students clubs as amateur associations that are created by interests and desires of students, have a clear goal, objectives, its controlling bodies, the appropriate organizational structure, charter, motto, etc. 
Ensuring of harmonious development of future specialist in tourism is impossible without complex approach of extracurricular activities organization in particular the formation of national consciousness, love to native land, its people, stimulating the need to acquire knowledge and professional skills, education of professional culture based on multicultural, historical, geographical and specific professional knowledge, the formation of professional responsibility, ecological education of future specialists in tourism, the formation of skills of dialogical and intercultural communication etc.

It is advisable extracurricular educational activities to be not limited by general educational activities but to be closely associated with the future profession.

As V. Zhuk considers for complex approach concerning organization of extracurricular education it is advisable to organize the work of 8-10 student clubs covering virtually all areas of education. It is clear that meeting of all clubs can not occur simultaneously but each club must have permanent place. Such availability of special facilities for clubs is not provided even in the newest projects of universities. Thus, under current conditions we should better use for clubs classrooms, laboratories, classrooms, etc. [5]. Classes of student clubs can be conducted in the form of mass or group activities. For the first option we require a large room and for the second one it is enough to have a classroom. Hours of student clubs are determined by schedule of extracurricular activities. Members of clubs in the major areas of education ideally should be all students. Here we can see a contradiction to the principles of voluntariness and complex approach and employment of students in extracurricular time.

Work of student clubs may not be limited to the walls of the higher educational establishment. It is because club life of students should be closely linked with the social environment. Clubs must base on relationships with businesses-orderers, customers, elementary schools, cultural institutions, creative organizations, companies, etc.. Moreover, their work must be based not on episodic events but on well-thought and planned system of joint activities with various social institutions.

\section{THE CONCLUSIONS AND PROSPECTS OF FURTHER RESEARCH}

The above mentioned features enabled to distinguish extracurricular educational work of students of higher educational tourist establishments. One of the most important conditions of this work is professionally oriented educational extracurricular activities using modern information technologies. For future specialists in tourism it is appropriate in extracurricular activities to plan series of educational affairs which are closely related to certain aspects of the future of professional activity: local history studies, excursions, organization of tourist interest clubs and etc.

Considerable role in professional activity of specialists in tourism is communication even by means of information technologies (Skype, social networks etc.). The main function of communication in tourism education is to exchange the results of cognitive activity between individuals, communication has determined influence on perceptual, mnemic, mental, attentive personality characteristics. Besides, communication is linked with emotions that regulate human communication. Positive emotions increase the ability to memorize and reproduce. Emotionally saturated, rich in axiological images of tourist excursional routes form the personality develop its psychological processes and behavior [11]. Multicultural environment in which a tourist is, optimizes not only psychological processes but also the processes of personality development and social relations. It provides regulations of various relationships among the participants of tourist activity because according to the nature of their own existing they are subjective (define activity of tourism organizers and various activities of subjects of tourist activities, reflect the inner essence and meaning of their activities; determine the social and applied direction of educational process and activity organizers of 
tourism, determine the nature and peculiarities of various activities of tourism subjects, define interdependence of all components of educational process in general etc.).

Educational measures should promote formation of skills and abilities of labour culture, interest motivation to professional and human values. Future specialists should gain profound knowledge of modern innovations and implement them in real life in multicultural world. Cultural approach in the education of future specialists in tourism is of great importance. Educating of national self-consciousness, feeling of pride and respect for national history, culture, traditions and customs of Ukrainian people should be organically combined with respect and tolerance towards people of other nationalities, especially in the process of international tourism activities.

Thus, the determination of the content, methods and forms of educational extracurricular activities in training of future specialists in tourism involves the integrity of the process of education in tourism and the interdependence of its components and tourist education is guided by educational objective as well as by the implementation of the principles and laws of education and modern information technologies, i.e. Internet, mass media etc. Terms of efficient organization of educational work in extracurricular activities is its professional direction, formation of professional culture and capacity for intercultural communication in a multicultural environment, interest motivation to professional and human values etc.

To further directions of research we consider the problem of scientific-pedagogical and methodological training of teachers and curators of groups to extracurricular educational work with students taking into consideration the peculiarities of professional training of future specialists in tourism.

\section{REFERENCES}

1. Виховна робота в закладах освіти України // Збірник нормативних документів та методичних рекомендацій з питань організації виховної роботи .ІСД. - К. : 1995. - 135 с.

2. Галєєва А.П. Організаційно-педагогічні умови виховної діяльності у вищому аграрному навчальному закладі : автореф. дис. на здоб. наук. ступ. канд. пед. наук : спец. 13.00.07 “Теорія і методика виховання" /А.П. Галєєва.- Дрогобич, 2009. - 20c.

3. Дзюба В.І. Соціально-педагогічні основи формування гуманістичних ціннісних орієнтацій студентської молоді: Дис. ... канд. пед. наук: 13.00.05. - Київ, 1994. - 225 с.

4. Довгополова Я.В. Формування толерантних відносин студентів у полікультурному середовищі вищого навчального закладу: дис. ... канд.пед.наук: 13.00.05. - Харків,2007. - 206с.

5. Жук В.П. Навчально-виховна робота у професійно-технічних навчальних закладах / В.П. Жук. Львів : Сполом, 2004. - 48 с.

6. Карпенчук С.Г. Теорія і методика виховання / С.Г.Карпенчук : навч.посібник. - К. : Вища.школа, 1997. - 304 c.

7. Макаренко А. С. Педагогика индивидуального действия. Лекция 3 / А. С.Макаренко Сочинения: В 7 т. - Т. 5 / Гл. ред. И. А. Каиров. - М. : Изд-во АПН РСФСР, 1957. - 224 с.

8. Осипова Т.Ю. Виховна робота зі студентською молоддю / Т.Ю.Осипова, І.О.Бартенєва, О.О.Біла та ін. : навч. посіб. / За заг. ред. Т.Ю. Осипової. - Одеса : Фенікс, 2006. - 288 с.

9. Палаткина Г.В. Мультикультурное образование: современный подход к воспитанию на народных традициях // Педагогика. - №5. - 2002. - С. 41-47.

10. Сухомлинська О.В. Про стан теорії і практики виховання в освітньому просторі України // Шлях освіти. - 1998. - №3. - С. 2-5.

11. Федорченко В. К. Педагогіка туризму : навчальний посібник для студентів вищих навчальних закладів / В. К. Федорченко, Н.А. Фоменко - К. : Слово, 2004. - 296с.

12. Business Education \& Information Technology [Електронний ресурс]. - Режим доступу : http://www.oregonsd.org/

13. Role of Information Technology in Tourism [Електронний pecypc]. - Режим доступу: www.fama2.us.es:8080/turismo/ 


\title{
ВИКОРИСТАННЯ ІНФОРМАЦІЙНИХ ТЕХНОЛОГІЙ У ВИХОВНІЙ ПОЗААУДИТОРНІЙ ДІЯЛЬНОСТІ ВИЩИХ НАВЧАЛЬНИХ ЗАКЛАДІВ ТУРИСТИЧНОГО ПРОФІЛЮ
}

\author{
Матвіїв-Лозинська Юлія Олександрівна \\ викладач англійської мови \\ Львівський інститут економіки і туризму, Львів, Україна \\ lozynskajuliya@yahoo.com
}

\begin{abstract}
Анотація. У статті йдеться про позааудиторну виховну діяльність у вищому навчальному закладі туристичного профілю 3 використанням інформаційних технологій. Відомо, що позааудиторна робота навчального закладу має вплив на професійну діяльність майбутніх фахівців з туристичної галузі, адже саме у процесі позааудиторної діяльності студенти можуть застосовувати на практиці здобуті під час занять знання та вміння. Завданням викладачів є побудувати навчальний процес, зокрема діяльність за межами аудиторій як його складову, таким чином, щоб студентам було цікаво. В сучасному світі процвітання туризму це дуже важко зробити без використання мультимедійних технологій (Інтернету, засобів масової інформації тощо).
\end{abstract}

Ключові слова: інформаційні технології; позааудиторна діяльність; фахівець; туристична галузь; виховання; вищий навчальний заклад.

\section{ИСПОЛЬЗОВАНИЕ ИНФОРМАЦИОННЫХ ТЕХНОЛОГИЙ В ОБРАЗОВАТЕЛЬНОЙ ВНЕАУДИТОРНОЙ ДЕЯТЕЛЬНОСТИ В ВЫСШИХ УЧЕБНЫХ ЗАВЕДЕНИЯХ ТУРИСТИЧЕСКОЙ ОТРАСЛИ}

\author{
Матвиив-Лозинская Юлия Александровна \\ преподаватель английского языка \\ Львовский институт экономики и туризма, Львов, Украина \\ lozynskajuliya@yahoo.com
}

\begin{abstract}
Аннотация. В статье говорится о внеаудиторной воспитательной деятельности в вузе туристического профиля с использованием информационных технологий. Известно, что внеаудиторная работа учебного заведения влияет на профессиональную деятельность будущих специалистов туристической отрасли, ведь именно в процессе внеаудиторной деятельности студенты могут применять на практике полученные во время занятий знания и умения. Задачей преподавателей является построение учебного процесса, в частности деятельности за пределами аудиторий как его составляющей, таким образом, чтобы студентам было интересно. В современном мире процветания туризма это очень трудно сделать без использования мультимедийных технологий (Интернета, средств массовой информации).
\end{abstract}

Ключевые слова: информационные технологии; внеаудиторная деятельность; специалист; туристическая отрасль; воспитание; вуз.

\section{REFERENCES (TRANSLATED AND TRANSLITERATED)}

1. Extracurricular activities in the educational institutions of Ukraine / / Proceedings of regulations and guidelines for the organization of educational work. ISD. - K.: 1995. - 135 s. (in Ukrainian)

2. Halieieva A.P. Organizational and pedagogical conditions of educational activities in higher agricultural educational establishment: Summary of PhD thesis : speciality 13.00.07 "Theory and Methods of Education" / A.P. Halieieva. - Drogobych 2009. - 20 s. (in Ukrainian)

3. Dziuba V.I. Social and Pedagogical Foundations of students' humanistic values forming : PhD thesis : 13.00.05. - Kyiv, 1994. - 225 s. (in Ukrainian)

4. Dovhopolova Y. Formation of students' tolerant relations in the multicultural environment of higher 
educational establishment : PhD thesis ...: 13.00.05. Kharkiv, 2007. 206s. (in Ukrainian)

5. Zhuk V.P. Educational work in vocational educational establishments / V.P. Zhuk. Lviv: Spolom, 2004.. - 48 p. (in Ukrainian)

6. Karpenchuk S.H. Theory and Methods of Education / S.H. Karpenchuk: manual. - K. Vyshcha.shkola, 1997. - 304 s. (in Ukrainian)

7. Makarenko A. Pedagogy of individual action. Lecture 3 / A. S. Makarenko works: The 7 volumes Vol 5 / Editor I.A. Kairov. - Moscow: Publishing House of the RSFSR Academy of Pedagogical Sciences, 1957. - 224 s. (in Russian)

8. Osypova T.Iu. Educational work with students / T.Iu. Osypova, I.O.Bartenieva, O.O.Bila etc. : Manual. / Edited by T.Iu. Osipova. - Odessa: Phoenix, 2006. - 288 s. (in Ukrainian)

9. Palatkina H.V. Multicultural education: modern approach to education of folk traditions// Pedagogy. - № 5. - 2002. - S. 41-47. (in Russian)

10. Suhomlynska O. On status of the theory and practice of education in the educational environment of Ukraine / / The way of education. - 1998. - № 3. - S. 2-5. (in Ukrainian)

11. Fedorchenko V.K. Pedagogy of tourism: a manual for students in higher educational establishments / V.K. Fedorchenko, N.A. Fomenko - K.: Word, 2004. 296s. (in Ukrainian)

12. Business Education \& Information Technology [online]. - Available from: http://www.oregonsd.org/

13. Role of Information Technology in Tourism [online]. - Available from: www.fama2.us.es:8080/turismo/ 